Univerzitet u Beogradu
Poljoprivredni fakultet
Institut za poljoprivrednu tehniku
Naučni časopis
POLJOPRIVREDNA TEHNIKA
Godina XLIV
Broj 4, 2019.
Strane: $17-26$

\title{
SMART SOLUTION FOR SAFE AND LONG-LASTING OPERATION OF AGRICULTURAL EQUIPMENT
}

\author{
László Magó ${ }^{* 1}$ \\ Department of Logistics and Materials Handling, \\ Institute of Engineering Management, \\ Faculty of Mechanical Engineering, Szent István University \\ Páter K. u.1. Gödöllö, H-2103, Hungary
}

\begin{abstract}
Nowadays the increasing of the efficiency of agricultural production and the increasing of crop yields cannot be achieved without modern digital technology and smart machines that are a part of it. With the spread of precision agriculture and the digitalisation next to the power machines the attached equipment is becoming smarter and smarter. Through permanent technological and IT development, it became possible to thoroughly monitor and analyse operating functions and parameters not only for the most important power machines such as tractors, combines and other, but also there are existing solutions for measurement - and related to that a collection and an analyse of data - of specific utilisation parameters for other attached equipment. All of these processed data are essential for making well-considered actions related to the production technology and the machine operating. They help us to gain information about the quality of machine operations of the technology, the environmental factors, or even about the state of attached working equipment and machines.

In this work, the vibration control system as smart solutions on the fail movers will be presented which are effective tools for the utilization of machines, for the precision machine work as well as for prolonging the machine life cycle.
\end{abstract}

\section{Keywords: Smart machines, Precision Agriculture, GPS, Data analysing, Vibration Control}

\section{INTRODUCTION}


Precision Farming did become a popular research field since the 1980s. Technologies have been developed all over the world to help the farmers raise crop yields and make agricultural production processes more efficient. This new developments steadily contribute to a higher productivity and show that this technology is very important. Electronic assistance systems, such as autonomous track guidance or section control are state of the art when investing in new machines on crop farms. [3] This technologies are efficient tools to improve sustainability and productivity in farming. Precision Agriculture technologies offer solutions to produce more with less. It is one of the biggest revolution in agriculture [5]. Practically, Precision Agriculture technologies provide farmers with extra sensors which give them more information on how to manage natural variations. [8] It is technical, environmental and management innovation that has come out of the strategic product and technology innovation phase, while the whole management system is sharacterized by continuous renewal and new, higher added value added, [19]. The aim of precision, or site specific agriculture is to handle within field variability with input materials to achieve the highest and sustainable profit. [2] The approach mainly benefits from the development of technologies like GPS, GIS, computer technology, automatic control, remote sensing and advanced information processing [9], [22, 23, 24, 25], and [28, 29], [30].

\section{MATERIAL AND METHOD}

\section{Smart Farming in Agriculture 4.0.}

"Smart Agriculture" and "Digital Farming" are based on the emergence of smart technology in agriculture. These technologies are using smart devices which consist of sensors, actuators and communication technology [13].

Digital systems, sensor techniques and technologies, remote sensing on different platforms, artificial intelligence including machine learning and deep learning, and in particular unmanned or quasi unmanned production systems are developing fast, and these are the tool for dynamic sustainability. In the future there will be the integration of these common players into smart transport, smart organisation, and smart landscape management by smart policy making. $[12,15,16,20]$

The term Agriculture 4.0 should be logical upgrading of Smart and Digital Farming. There is some possibility about how will Agriculture 4.0 impact the supply chain by better using of IT:

- Optimize the inputs (Precision Farming).

- Manage mechanization more efficiently \& use of energy resources.

- Enhance crop storage techniques \& reduce crop losses.

- Provide better information about market demand \& seasonal fluctuation.

- Improve transport \& logistics services.

- Optimize retailer stocking \& storage (less waste). [1]

The Smart Logistic System, integrated with the ERP (Enterprise Resource Planning), enables application of 4.0 industry approach. 
Its intention is to enable same application to agricultural machinery, e.g. for logging the seeding and fertilizing process (lot, operator, date, quantity) and remote diagnostic by using IoT ready systems. The advantages of own production applied utilization of digital information to trace the different materials and automate their handling, are listed following objectives:

- to reduce the material handling;

- to reduce the inventory failures;

- to implement flexibility with discipline;

- to find one place for everything and everything in its place;

- to set a FIFO (First In First Out) rule;

- to implement the material traceability. [17]

Automated data mining and -interpretation is becoming a critical element of agricultural industrial research. [10] Developments in agriculture which mine data and act almost autonomously on basis of these data can be summarized by the term "Agriculture 4.0" [6].

Some Precision Agriculture diagnostic technologies are already highly affordable and thus available to smaller farms thanks to smart phones or tablets and their applications, like in our presented study. Such applications can directly signal a problem on the field or connect to an online service for further probing. [8]

\section{Devices for Precision Farming in grassland}

In comparison to its widespread implementation on arable farms, Precision Farming in grassland is used rarely in practical farming. There was some efforts to measure the quantity of harvested grass to, amongst other things generate yield maps. Demmel et al. examined a weighing system in a conveyor belt, mounted at the rear part of a mower. [7] Kumhála et al. used methods to measure forage yield known from choppers or harvesters. They equipped a drum mower with a torque sensor and a curved impact plate (behind a mower conditioner) which was hit by the mowed grass. [14]

Some small smart applications already found their way into practice like a torque sensor for warning the driver if the rotation of the mower and the rotation of tractors power take off (PTO) distinguish too much to give him assistance for an optimum velocity and motor speed.

\section{The Company INO Brezice d.o.o.}

A Slovenian company INO Brežice produces a variety of mulching machines, vibrating subsoilers, fertilizer spreaders. Among the company's innovative products are so-called "Smart Solutions" which ensure a safe and efficient operating of their basic products:

- flail mowers by means of continuous measuring vibrations and detecting the outstanding ones,

- fertilizer spreaders and vibrating subsoilers by efficient specific electronic control of operating. [18] 


\section{RESULTS}

\section{Basic description of INO Vibration Control}

The Vibration Control System is a smart solution based on IoT principal, which consists of INO flail mower, sensor, smart mobile device and web application. It offers to the user an online information about working conditions for professional agricultural and communal machines. The main purpose for using INO Vibration Control is to control vibrations on the machine that means flail mower, arm mower or similar (Figure 1.). The sensor is measuring the level of vibrations which are sent to the mobile device. The mobile device stores GPS coordinates, a time stamp and $\mathrm{x}, \mathrm{y}, \mathrm{z}$ axe vibration levels and temperature through all working process for each second.

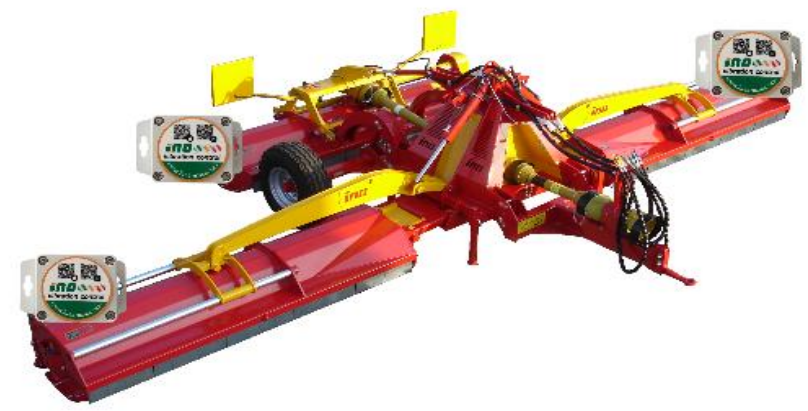

Figure 1: The position of the vibration sensors on the working machines, actually on the flail mower machine [11].

\section{Innovation character}

The goal of this system is to control the level of vibrations on flail mowers and consequently also on other machines, used for public utilities and for agricultural land cultivation, where the level of vibration in allowed area is one of the key features for correct, safe and long-lasting operation. Data compilation, collection of information is continued also in the direction of other telemetric information for the purpose of work control on cultivated land, data import from the phone, drawing-up of the surface in online graphic folders and keeping track of various attributes on an individual cultivation area, e.g. number of mowing, amounts of yield, fertilization, quantity, working temperature, speed of movement, location, etc.

Usability and advantages of system are globally as follows:

- control of machine operation,

- control of the operator's work,

- measuring productivity,

- communication between sensor and mobile device without vendor lock limitations

- online vibrations control level to enable safe, long-lasting operation and to decrease the maintenance costs

- mobile application for Android and iOS system 
- telemetric data for determination of productivity level of the end user (tractor operator)

- simple Enterprise Resource Planning web based application

- useful analytical synthesis data for the extension of the warranty

- independence from different payable systems,

- saving measured data,

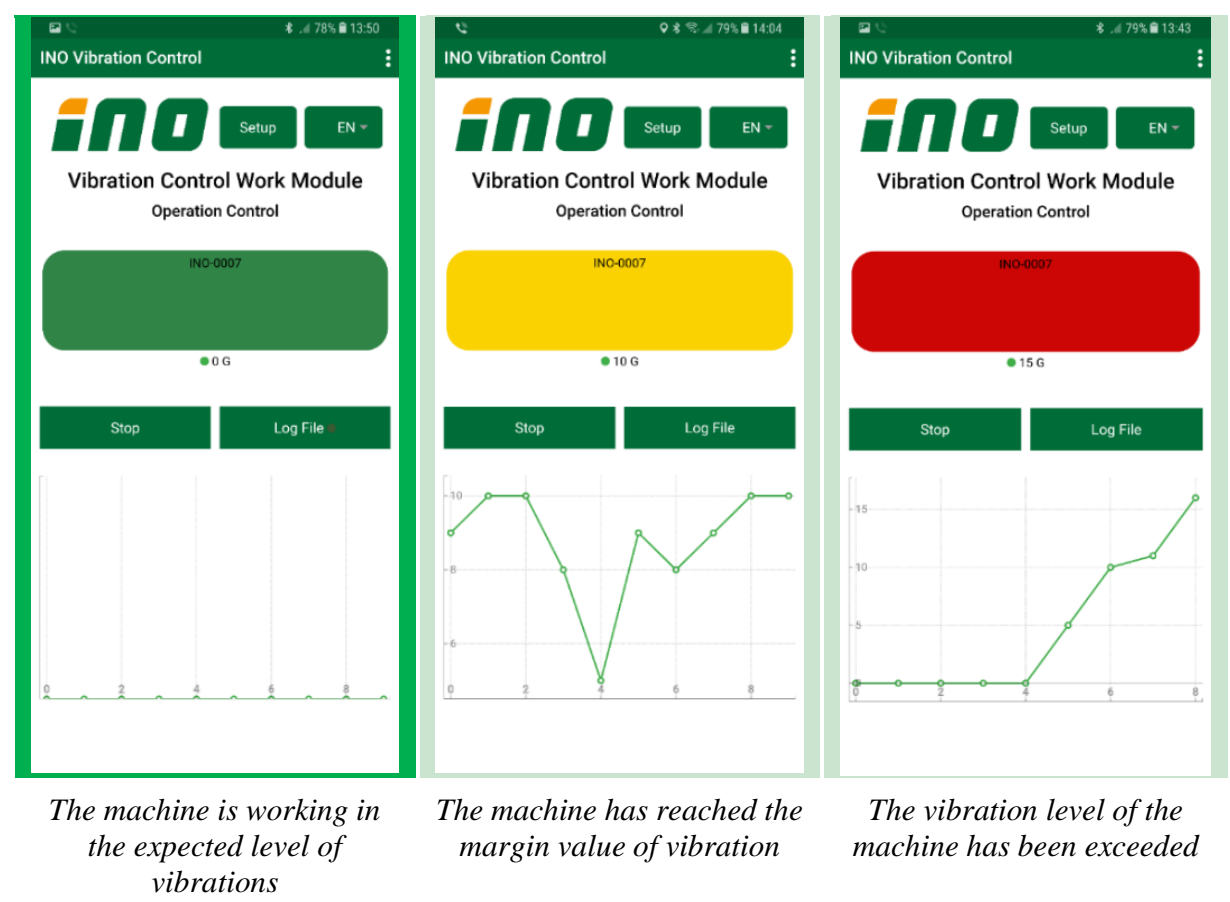

Figure 2: Three level of vibrations, normal, marginal, and excessive, showing on the mobile phone, [11].

The program package is developed for different users:

a) operators-tractor drivers

- alert if the engine hits something

- alert if too high vibrations are on the engine (see Figure 2.)

- alert when low battery

b) supervisors at the desk:

- too high vibrations are on the engine

- engine is working in wrong time and/or on wrong area

- the exact place where the engine is working in the exact time

c) analysts-reporters:

- full report and analyse of working productivity including of working time and stops, working area, vibrations and alerts for each engine, details of surface covering, tracking and so on

- Application with program package without use the sensor, adapted to the buyer's needs (possible all up-mentioned data except vibrations) [21] 


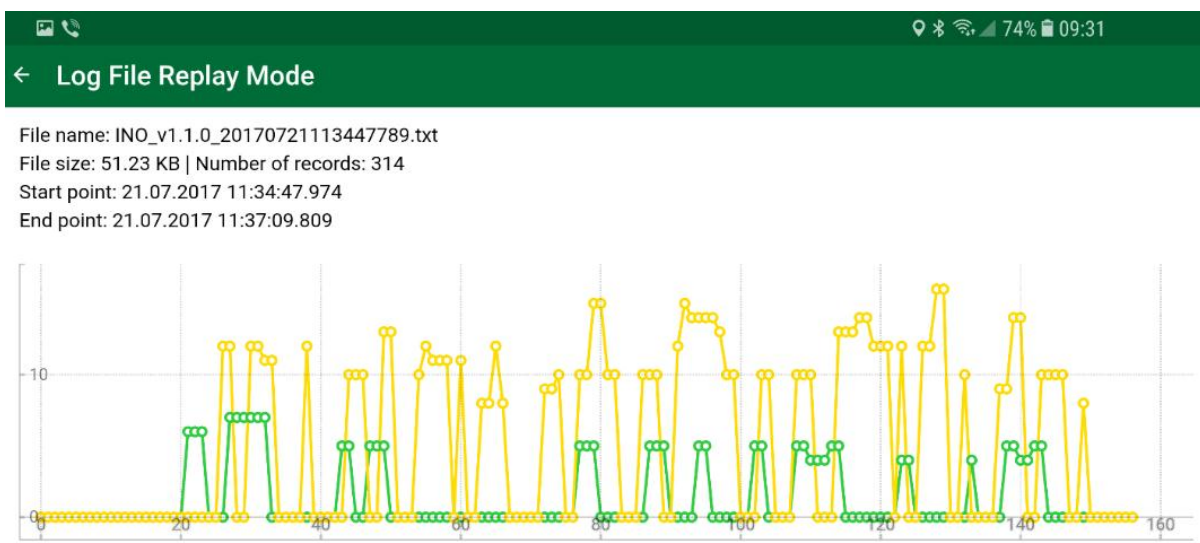

Figure 3: The history of the measured data on the Mobile Phone Screen [11]

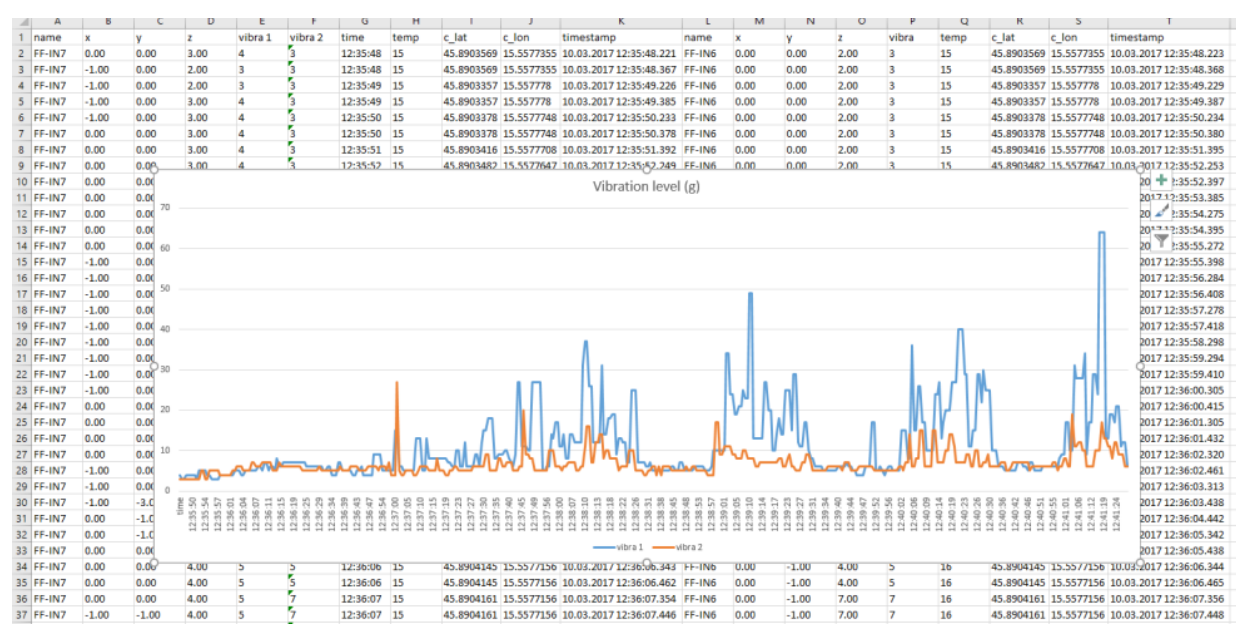

Figure 4: The history of the measured data on the Computer Screen, [11].

The mobile application could provide the user with the next information:

- Emergency SMS service (send SMS with current location to selected contact)

- Send SMS for detection of machine stop (to selected contact)

- Send SMS for excessive vibrations (to selected contact)

- Option for use only as GPS tracking (no INO sensors needed)

- Show on Map for Log Files (with vibration data markers) [21]

The measured sensor data can be stored to the mobile device. The user can read stored data for each second of recording: 
GPS coordinates, vibration levels by $\mathrm{X}, \mathrm{Y}$, and $\mathrm{Z}$ axis, temperature and exact time. Stored data can be exported to another device or computer and later analysed in one of the required applications (for example: MS Excel), or can be viewed directly on a mobile device. (Figure 3., 4.)

\section{CONCLUSIONS}

For small, medium-sized, and for the large-scale farm machinery too, the abovementioned Smart Solutions prove to be beneficial for efficient work, professional utilization of machines, and for minimizing the production and mechanization costs.

A common feature of systems described in this article is that they can be operated independently from the tractor's ISOBUS system. Both, the controller as well as the data collecting interface can be operated autonomously using their own system by means of a mobile phone or tablet device that can be controlled via wide spread accessible mobile application.

It is very important to mention that there are some advantages of IT, but some problems as well. Most significant are those related to putting systems into the operation and fighting with malfunctions. One of specific problem is coupling the tractors and implements by using different stages of ISOBUS. That means, full commercial maturity of compatibility of ISOBUS is still in front of us. [4]

The design of these electrical systems can also be realized by an individual, innovative medium-sized machine manufacturing company, as it is shown in the presented work.

\section{REFERENCES}

[1] Adam U. (2017). Agriculture 4.0 - the Challenges Ahead and What to Do about Them - 27th Club of Bologna Meeting, Hannover, 12-13 Nov 2017. 31 p.

[2] Auernhammer H.: (2001) Precision Farming - the Environmental Challenge. Computers and Electronics in Agriculture. Vol 30. 1-3. pp 31-43.

[3] Bauerdick J., Piringer G., Kral I., Gronauer A., Bernhardt H.(2017). Precision Grassland Farming - State of the Art and Future Research Topics. Proceedings of the 45th International Symposium Actual Tasks on Agricultural Engineering. Opatija, Croatia, 21 - 24 February 2017. p. 303 - 309.

[4] Bosch J. (2018). Farmer's Experiences with New Technologies in Agriculture - 28th Club of Bologna Meeting, Bologna 10 Nov 2018, 16 p.

[5] Crookston K.: (2006) A Top 10 List of Developments and Issues Impacting Crop Management and Ecology During the Past 50 Years. Crop Science, 46, 2253-2262.

[6] Clasen M. (2016). Farming 4.0 und andere anwendungen des internet der dinge. In Ruckelshausen, A. et al. (Eds.), Proceedings of GIL annual meeting 2016. Informatik in der Land-, Forst- und Ernahrungs-wirtschaft. Fokus: Intelligente Systeme-Stand der Technik und neue Möglichkeiten (pp. 15-18). Bonn: Koellen.

[7] Demmel, M., Schwenke, T., Heuwinkel, H., Locher, F., Rottmeier, J. (2002). Ertragsermittlung von Grünland - erste Ergebnisse. In: LANDTECHNIK - Agricultural Engineering 57 (3), pp. 146-147. 
[8] Dryancour G. (2017). Smart Agriculture for All Farms, CEMA - European Agricultural Machinery Association, Brussels, Belgium, 23 p.

[9] Gibbons G.(2000). Turning a Farm Art into Science / an Overview of Precision Farming. http://www.precisionfarming.com

[10] Horstmann, J. (2016). Kommunikationssysteme und Farming 4.0 in der Landtechnik. In: Jahrbuch Agrartechnik 2015 (L. Frerichs). Braunschweig, pp. 1-7. Available online at http://www.jahrbuch-agrartechnik.de/index.php/artikelansicht/items/230.html, checked on $4 / 12 / 2019$.

[11] INO Vibration Control System User Manual (2018). INO Brežice, Slovenia, Krška vas, 6. p.

[12] Kempenaar C.C.et al.:(2016). Towards Data-intensive, more Sustainable Farming: Advances in Predicting Crop Growth and Use of Variable Rate in Prediction Crop Growth and Use of Variable Rate Technology in Arable Crops in the Netherland. $13^{\text {th }}$ International Conference on Precision Agriculture. July 31 - August 4. St Louis, USA.

[13] Kovács I., Husti I. (2018). The Role of Digitalization in the Agricultural 4.0 - How to Connect the Industry 4.0 to Agriculture? Hungarian Agricultural Engineering, Periodical of the Committee of Agricultural and Biosystem Engineering of the Hungarian Academy of Sciences, Vol. 33. pp. 38-42.

[14] Kumhála, F., Kroulík, M., Prošek, V. (2007). Development and evaluation of forage yield measure sensors in a mowing-conditioning machine. In Computers and Electronics in Agriculture 58 (2), pp. 154-163. DOI: 10.1016/j.compag.2007.03.013.

[15] Lundström Ch., Lindblom J. (2016). Considering Farmers' Situated Expertise in Using AgriDSS to Foster Sustainable Farming Practices in Precision Agriculture. $13^{\text {th }}$ International Conference on Precision Agriculture. July 31 - August 4. St Louis, USA.

[16] Neményi M. (2018). Research Activity in PA in the Last Decade in Terms of Sustainability (Thoughts about the Future). in PREGA Science - Papers presented at the 2nd Sci. Conf. on Percision Agriculture and Agro-Informatics (Edited: Milics G.) p. 12-16.

[17] Oliaro F. (2017). Smart Logistic for Effective Process - 27th Club of Bologna Meeting, Hannover, 12-13 Nov 2017, 14 p.

[18] Šubic P. (2017). Po kakovosti mulčerjev je INO Brežice med top 5, Časnik Finance, https://agrobiznis.finance.si/8856030/Po-kakovosti-mulcerjev-je-Ino-Brezice-med-top-5

[19] Takácsné Gy. K. (2018). The Innovation Process of Precision Crop Production - Along with Economic Theories, in PREGA Science - Papers presented at the 2nd Sci. Conf. on Percision Agriculture and Agro-Informatics (Edited: Milics G.) p .17-19.

[20] Urso L-M. et al. (2017). Crop Production of the Future-possible with a New Approach. Proceeding of Advances in Animal Biosciences: Precision Agriculture. Edinburgh, UK. pp. 734-737.

[21] Vučinić Z. (2018). INO Vibration Control Presentation, Some Useful Data. INO Brežice, Slovenia, Krška vas, 2. p.

[22] Kosta Gligorević, Mićo V. Oljača, Đukan Vukić, Ivan Zlatanović, Branko Radičević, Miloš Pajić, Rade Radojević, Vladimir M. Oljača, Zoran Dimitrovski .(2009). Application of Can Bus Networks on Tractors and Working Machines. Scientific Journal of Agricultural Engineering No.1.,Vol .34., pp.115-121.

[23] Oljača V. Mićo, Pajić Miloš,Gligorević Kosta, Dražić Milan, Zlatanović Ivan, Aleksandra Dimitrijević, Rajko Miodragović, Zoran Mileusnić, Rade Radojević, Milovan Živković, Dragan Petrović, Dušan Radivojević, Mirko Urošević,Goran Topisirović, Branko Radičević, Olivera Ećim, Nebojša Balać (2018). Design, Classification, Perspectives and Possible Applications Drones in Agriculture of Serbia. Scientific Journal of Agricultural Engineering No.4.,Vol .43., pp. 29-56. 
[24] Mićo V. Oljača, Kosta Gligorević, Milorad Branković, Zoran Dimitrovski, Dragi Tanevski (2005). Electronic Equipments on Tractors And Working Machines in Functions of Higer Control of Sicurity and Exploatation. Scientific Journal of Agricultural Engineering No.1,Vol . 30., pp. 107-118.

[25] Rajko Radonjic, Aleksandra Jankovic, Dragoljub Radonjic, Jasna Glišović. (2011). Information Technologies in Function of Agricultural Technique Development. Scientific Journal of Agricultural Engineering No.3, Vol .30., pp. 51-58.

[26] Radonjić, R. (2007). Software Development to Simulation of the Soil Cultivation Process. Scientific Journal of Agricultural Engineering No.3,Vol .32., pp. 19-24.

[27] Marko Bogdanović, Mićo V. Oljača. (2010). Control of Parameters of Drip Irrigation Tehnical System. Scientific Journal of Agricultural Engineering No.3,Vol .35., pp. 15-23.

[28] Kosta Gligorević, Mićo V. Oljača, Lazar Ružičić, Rade Radojević, Miloš Pajić. (2007). Influence of Electronic Systems on Off Road Vehicles Stability. Scientific Journal of Agricultural Engineering No.3.,Vol .32., pp.11-18.

[29] Mićo V. Oljača, Đukan Vukić, Đuro Ercegović, Dušan Radivojević, Nebojša Momirović, Goran Topisirović, Kosta Gligorević, Branko Radičević, Vladimir M. Oljača. (2008). Wireless Sensors in Agriculture, Carrent Development and Future Perspective. Scientific Journal of Agricultural Engineering No.1.,Vol .33., pp.7-20.

[30] Momirović N., Vasić B., Oljača V.M. (2007). Tehnički sistemi za kontrolu mikro klime u plastenicima, Naučni časopis Poljoprivredna tehnika, No 4., Vol.32., str. 55-72.

\title{
PAMETNA REŠENJA POLJOPRIVREDNE OPREME ZA SIGURNO UPRAVLJANJE NA DALJINU
}

\author{
László Magó ${ }^{* 1}$ \\ Department of Logistics and Materials Handling, \\ Institute of Engineering Management, \\ Faculty of Mechanical Engineering, Szent István University \\ Páter K. u.1. Gödöllö, H-2103, Hungary
}

Sažetak: U današnje vreme povećanje efikasnosti poljoprivredne proizvodnje i povećanje prinosa useva ne mogu se postići bez priemne savremenih digitalnih tehnologija i "pametnih" mašina. Sa većom primenom precizne poljoprivrede i digitalizacijom, pored pogonskih mašina, i priključna oprema i mašine postaju sve "pametnije". Kroz stalni tehnološki i informatički razvoj, postalo je moguće detaljno nadgledati i analizirati radne funkcije i parametre, ne samo pogonske mašine, kao što su traktori, kombajni ili druge slične, već i postojeća rešenja koja uključuju merenje i analizu podataka i specifičnih parametara upotrebe za priključenu opremu i mašine.

Svi dobijeni i obrađeni podaci sa sistema mašina su od suštinske važnosti za dobro i uspešno korišćenje proizvodne tehnologije u radu mašine.

"Corresponding Author. E-mail address: Mago.Laszlo@gek.szie.hu 
Merni i kontrolni sitemi na mašinama pomažu da se dobiju: informacije o kvalitetu rada mašina u primenjenoj tehnologiji, faktorima životne sredine ili čak stanje i ispravnost rada priključene radne opreme i mašina.

U ovom radu je predstavljen sistem za daljinsku kontrolu i merenje vibracija na mašinama, kao pametno rešenje za pokretače (i uzroke) kvarova koji su efikasno sredstvo za korišćenje mašina, precizan rad i time produženje životnog ciklusa mašine.

Ključne reči: pametne mašine, precizna poljoprivreda, GPS, analiza podataka, kontrola vibracija

Prijavljen:

Submitted:

Ispravljen:

Revised:

Prihvaćen:

Accepted:

07.06.2019.

10.09.2019

30.10 .2019 